\title{
Traditional and Digital Game Preferences of Children: A CHAID Analysis on Middle School Students
}

\author{
Zeynep Tatli \\ Karadeniz Technical University, Turkey
}

\begin{abstract}
The purpose of this study is to determine types of games that middle school students play in their daily lives and analyze the effects of various variables such as gender, available technology, grade in school and parents' education levels on their game preferences. The sample consisted of a total of 464 grade 5-8 students ( 212 girls and 252 boys). The study was conducted in Spring 2015 and the data were collected using a two-part survey. The first part of the survey included questions about demographic information and the second part asked students to draw a picture of their favorite games. The results of this study showed that girls mostly preferred to play outdoor games whereas boys mostly preferred to play digital games. Participant students preferred to play games with rules outdoors and symbolic games indoors, and in digital environment, girls preferred to play minigames whereas boys preferred to play sports games. CHAID analysis was used in determining the relationships between the variables and game preferences. Gender was a prominent factor in identifying the preferences; that is, girls' game preferences were mainly influenced by having a computer and those of boys were affected by having an available Internet connection. This study also found that parents' education level is not related to children's game preferences. At the end of the study, suggestions were made for gamification and digital game design.
\end{abstract}

Keywords: Digital games; CHAID analysis; Middle school students; Gender differences; Game motivation

\section{Introduction}

A game can be defined (Oxford English Dictionary, 2016) as "an activity that one engages in for amusement or fun" and games are very important for child and youth development because they contribute to their cognitive, physical, social, and emotional well-being (Batdi, 2017; Goldstein, 2012). Similarly, Jenvey and Jenvey (2002) defined a game as an essential factor for child development in terms of social, emotional, physical, and cognitive skills. According to Miller and Kuhaneck (2008), a game is a child's primary and most important occupation as a way to prepare them for the future. Huizinga (2017) described a game as a free activity that enhances players' intrinsic motivation. It is generally accepted that games prepare children physically and cognitively for life and they are tools that improve their creativity, develop their problem-solving skills and enhance their feeling of freedom (Mclnnes \& Birdsey, 2013). There is a great potential of using games as a learning environment. Studies have shown that using games to engage students in the process of learning can improve the quality of education (Bakar, Tuzun \& Cagiltay, 2008). 
Asimoglu (2012), as a result of a study on teaching preschool students traditional games via creative drama, stated that by the help of drama, students' interest in the subject increased, the subject triggered curiosity, and rhythmic, musical and kinetic skills developed.

Birsen (2017), based upon a study where they achieved foreign language education via the method of game-based learning using a modernized form of traditional games, Pictionary, for students on the level of primary education, found that the success and perceptions of students regarding learning words increased, and stated that traditional games should be utilized as an effective factor in increasing interest towards and performance in a subject.

Iwata, Yamabe, Polojarvi and Nakajima (2010) stated that card games are still attractive, and the emotional effect of a game is increased by tangible game objects and spatial interaction. Traditional games develop children's learning, creativity, imagination and social connections (Parson, 2011). Most parents and educators agree that playing is essential for healthy development of children (Clements, 2004).

Huizenga, Admiraal, Akkerman, ten Dam (2009) found as a result of the study they conducted for teaching history to middle school students using digital games that the success of students in the learning field increased significantly and they were more willing to attend activities.

Kula and Erdem (2005), in their study on providing primary education students with arithmetic skills via educational digital games, determined that students' quantitative success did not change, but their qualitative responses changed from simple to more complex. Additionally, they reported increases in students' in-class interactions and motivations towards the subject. In general, it is seen that it was attempted to support traditional learning environments by games, dramatization and card games (Amory \& Seagram, 2003), and gather learners together with different interfaces such as 2D, 3D augmented-reality-supported platforms and massively multiplayer online role-playing games (MMORPG) (Hamalainen, 2008; Zhong, 2011). Games, which have an important place in the instruction process, are also preferred to create competition, challenges, social communication, diversity, and dreamy environments (Amory, Naicker, Vincent \& Adams, 1999; Bakar, Tuzun \& Cagiltay, 2008; Lucas \& Sherry, 2014).

Prensky (2002) listed the characteristics of students of the 21st century, whom he defined as digital natives, as multitasking, preferring graphical content more, wanting to reach information fast, technology-friendly, and preferring to learn by discovering and gaming. These characteristics lead us to digitalization and elements of games. Characteristics of digital games such as active participation in the process, customization for the user, socializing in the virtual environment, entertainment, sense of success and rewarding the user overlap with the characteristics of digital natives completely (Agaoglu \& Metin, 2015; Downey, Hayes \& Brian, 2004; Esen, 2008; Inal \& Cagiltay, 2005; Nedim Bal \& Metehan, 2016; Van Rheenen, 2012). Accordingly, it may be argued that digital games are some of the most ideal learning environments for digital natives and the generation in question learns best via games (Karlsson, 2007; Kiili, 2005; Prensky, 2003).

Studies reported that, while the time spent by children playing games at home and in video game arcades was 4 hours a week on average in 1980s; this time increased up to 5.5 hours for girls and 13 hours for boys in 2004 (Christakis, Ebel, Rivara \& Zimmerman, 2004; Fis Erumit, 2016), and it was suggested that it is a necessity to include this game-playing time in the time children spent learning (Fromme, 2003; Funk, 1993). 
In addition to contributing to the learning of students in a relevant field, digital games are known to increase students' attention and motivation via fun learning environments that are created in games, and contribute to development of self-esteem and self-efficacy, problemsolving, and strategic and algorithmic thinking skills (Akpinar, 1999; Batdi, 2017; Bayirtepe \& Tuzun, 2007; Bottino, Ferlino, Ott \& Travella, 2006; Demirel, Seferoglu \& Yagci, 2003; Prensky, 2001). With these characteristics, digital games provide children with opportunities for learning. For example, they experience being a pilot while using plane simulators or being an engineer while building cities. Therefore, it is clear that learning environments prepared by considering student characteristics, readiness levels and experiences will create more meaningful learnings for them (Garris, Ahlers \& Driskell, 2002; Gunes, 2015; Karamustafaoglu \& Kaya, 2013; Tural, 2005). The Turkish Ministry of National Education also includes more efforts in recent years in this regard for developing digital games for almost every subject (URL-2017). For this process to be effective and learning-based, one needs to look at the theoretical basis of game-based learning.

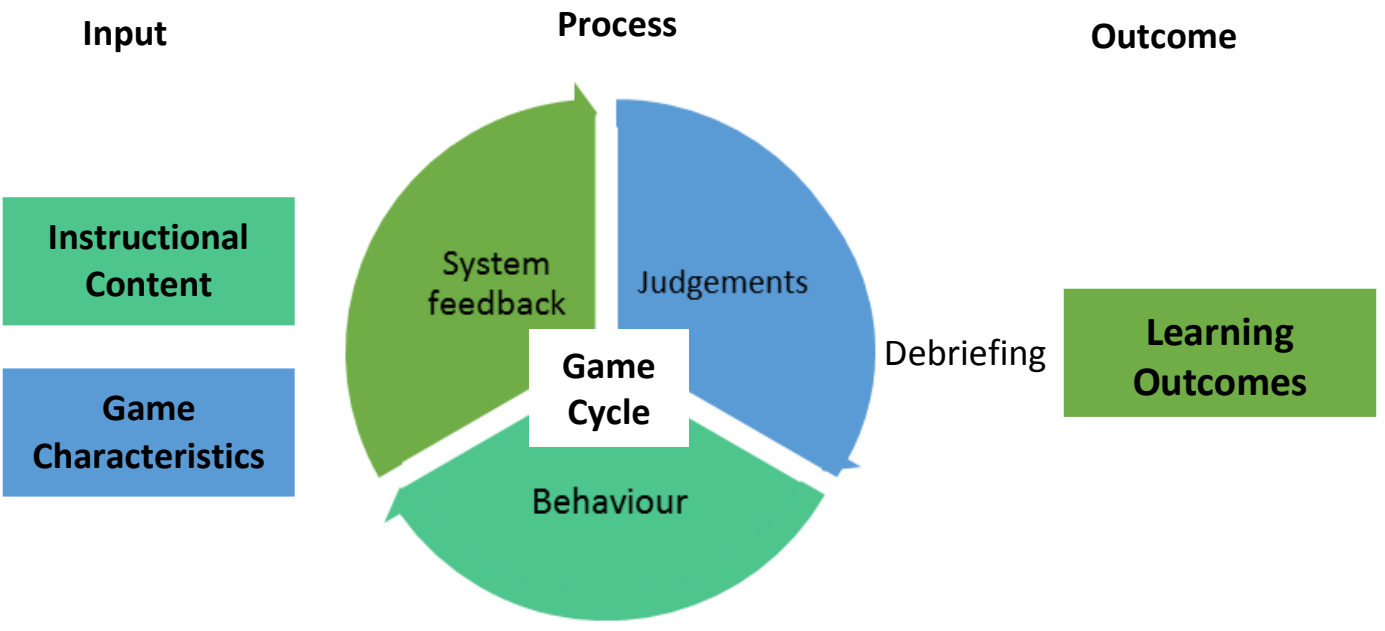

Figure 1. A Model of Game-based Learning [Garris, Ahlers \& Driskell, 2002]

Game-based learning used games as a reinforcing/complementary factor in order to develop capability in specific subjects. Such games either provide preliminary learning or replace learning (Cankaya \& Karamete, 2008; Kearney \& Pivec, 2007). In difference to gamification, this does not concern the entirety of the learning process (Arabul Yayla, 2015; Karatas, 2014; Sahin et al., 2017). As in the chart that represents the learning process as given in the figure above, in the game cycle into which educational content and the game enter together, educational content is in a blurred formation with the characteristics of the game (Prensky, 2001). The response to the action of the player comes through feedbacks from the system. The player, this way, starts to discover the structure in the game and adapt to the discovered structure (Kula \& Erdem, 2005; Prensky, 2001). The connection between the game cycle and learning outputs occurs in the process of questioning. This process involves the players' adoption and application of what is learnt in the game in real life (Garris, Ahlers \& Driskell, 2002). Learning outputs following the process of questioning may be generally listed as cognitive, sensory and motor skills (Deterding, Dixon, Khaled \& Nack, 2011). It should be ensured that the outcomes in question are provided to the player in the cycle of experience by dividing these outcomes into small steps. The emotional dimension of the game is about achieving a given task. A game rewards the player with points, cups, etc. in exchange of success. Failure leads to removal of 
the player from the given task (Domínguez et al., 2013). The most important concept here is the motivation of the player. If the motivation is achieved from within the student without the need for an external influence, this is internal motivation. Internal motivation is performance of learning activities by a person's own will (Fis Erumit, 2016).

It is stated that especially the educational games in digital environments will not only support their active participation in the process but contribute to their interactions with peers and connection to the process of learning (Caglar \& Arkun Kocadere, 2015), and when entertainment, motivation and dedication to the setting are prioritized in addition to learning, quality will also increase (Cankaya, 2007). It was hoped that the educational potential of educational digital games developed with this purpose would be strong, but it was seen that, in comparison to entertainment-oriented games, educational games did not attract students or increase attention and motivation much (Kula \& Erdem, 2005). Theory and practice, unfortunately, did not comply with each other (Fis Erumit, 2016).

It seems possible to transform the games students play with great motivation and desire into a more efficient form by collaboration between the educators and the game sector (Korkusuz \& Karamete, 2013). Being able to determine which types of games students prefer and the games and locations that get pleasure out of playing, is only one dimension of studies that will pave the way to add educational content into games without disrupting their playability and fun (Bozkurt \& Genc Kumtepe, 2014; Catak, 2011; Dickey, 2007; Hacisalihoglu Karadeniz, 2017; Tolay, 2013; Tugrul et al., 2014). This study aimed to determine the games middle school play willingly and fondly play and present the variables that affect game preferences. In this context, answers were sought for the following questions:

\section{Methods}

There are different methods and techniques that aim to identify game preferences of students. Vance, Miller and Hand (1995) argued that cognitive structure may be revealed by using different methods and strategies in order to determine current situations of minds and conceptual changes. These alternative assessment and evaluation techniques are used to determine not only students' possessed knowledge, but also the way students relate concepts, their cognitive structures, to what extent they understand the similarities between their possessed knowledge and daily events in their surroundings (Bahar, Nartgun, Durmus \& Bicak, 2006) and alternative concepts that they build (Kurt et al., 2013). The-Draw-and-Write technique, which is one of the most important measurement tools, was utilized in this study in order to identify the participants' game preferences. Especially drawing enables children of all ages to reflect on their own cognitive situation and how they learn (Aydogdu \& Kesercioglu, 2005). Several studies have used the drawing method in order to reveal the possessed knowledge of students about specific subjects (Ehrlén, 2009; Harman, 2012; Sahin, Ipek \& Ayas, 2008).

The quantitative research method of survey was used in this study to determine middle school students' game preferences. The survey method is defined as a scientific research tool that enable researchers to make generalizations on the population from the sample being studied (Johnson \& Christensen, 2000). In other words, survey research aims to describe or explain characteristics of a very large group or groups such as societies, things, institutions and events (Cohen, Manion \& Morrison, 2007; McMillian \& Schumacher, 2001). Since this study aims to 
define the game preferences of middle school students, it was thought it would be useful to form a very large sample out of 464 students and employ the survey method.

\section{Participants}

In the scope of the study, 478 middle school students were reached from 12 randomly selected schools in the central district and other districts of the province of Trabzon in Turkey. 10 student who did not respond to the survey in the study completely and 4 students who made more than 4 game drawings were left out of the sample. The remaining 464 middle school students ( 212 girls, 252 boys) of grades 5, 6, 7 and 8, from different socioeconomic groups constituted the sample.

A total of 464 participants were included in the study. Table 1 demonstrates participant students' gender and grade level information. As shown in Table 1, 464 students participated in the survey. This number included 212 girls and 252 boys.

Table 1. Distribution of Participants by Grade in School and Gender

\begin{tabular}{lllll}
\hline Grade & $\mathbf{5}$ & $\mathbf{6}$ & $\mathbf{7}$ & $\mathbf{8}$ \\
\hline Girl & 48 & 47 & 59 & 58 \\
\hline Boy & 65 & 49 & 67 & 71 \\
\hline Total & 113 & 96 & 126 & 129 \\
\hline
\end{tabular}

\section{Data Collection Tool}

The data of this study, which was conducted in Spring 2015, were gathered by using a two-part survey. This two-part survey was developed according to three different field expert-opinions. The first part consisted of demographic questions and the second part asked students to draw a game that they had the most fun playing (the most played games). A pilot study was conducted with 50 students, who were not included in the sample of this study, in order to test the survey questions. The pilot study showed that 30-40 minutes of time was enough to complete the survey. Additionally, two questions that were generally misunderstood by the students were redesigned and the final survey was obtained.

\section{Data Analysis}

The SPSS 20.0 software was used in the quantitative data analysis, while the qualitative data analysis involved the method of content analysis, which comprises stages of coding, finding themes, organizing the data based on codes and themes (Yildirim \& Simsek, 2011). The drawings in the survey forms filled out by the students were coded by transcription. For reliability of coding, two different experts of the field performed coding on randomly selected examples and compared the results. The relationships among the codes were examined, similarities and differences were detected, and the main lines of the finding of the study were derived. In this context, while developing the categories, three levels (indoor games, outdoor games and digital games) were determined in accordance with the body of literature and the content of the drawing questions (Yengin, 2012). Additionally, the three levels mentioned 
above were sub-categorized as games with simple rules, games with rules and symbolic games (Barnes, 2004; Pilten \& Pilten, 2013). The drawings of the students were categorized accordingly and are shown in the tables. The demographic data are presented as percentages and frequencies. In a qualitative study, it is important in terms of achieving validity in the study to report the data in detail, included direct quotes from individuals and explain the results (Yildirim \& Simsek 2011). An example of a drawing for each category was presented in tables based on mutual decision.

The factors that affect students' game preferences are determined by CHAID analysis, a decision tree method. The difference of CHAID analysis from other comparative analyses (such as t-test, ANOVA) is that it clusters the independent variable based on a certain dependent variable and starts a new clustering operation on the derived sub-clusters based on other independent variables. This way, while it analyzes the dependent variable in terms of the independent variables, it produces a result by evaluating various independent variable (Kilmen \& Kosterelioglu, 2017).

In general terms, as depicted by Kass (1980), decision trees are nonlinear methods that incrementally divide independent variables into smaller groups (Ture et al., 2005). CHAID analysis is an effective decision tree that repeatedly splits subsets of the space into two or more nodes, beginning with the entire data set (Michael \& Gordon, 2004). To identify the best split at any node, any allowable pair of categories of the predictor variables is merged. The splitting continues until there is no statistically significant difference within the pair with respect to the target variable (Kass, 1980).

CHAID is useful for analyzing a large number of predictor variables, and unlike similar statistical analyses, the CHAID algorithm does not require the data to be normally distributed or need assumptions such as homogeneity of the variants (Horner, Fireman \& Wang, 2010). The only required assumption for CHAID analysis is to identify scale types of the predicted and predictor variables (SPSS, 2012).

CHAID was preferred in this study because it also enables simultaneous analysis of nominal, interval and ratio scale data and demonstrates the relationships between the predicted and predicting variables in detail including all possible hierarchy (Yildiz, 2006; Horner, Fireman \& Wang, 2010).

\section{Findings}

This study aimed to answer four research questions. The findings are presented below under subcategories.

\section{Findings Related to Game Environments of the Students and Games That They Played}

Findings related to game environments of the students and games that they played were categorized in accordance with the evaluations of the students' drawings, and these are shown in Table 2 in percentages. 
Table2. Types of Games That the Participants Reflected in Their Drawings

\begin{tabular}{|c|c|c|c|c|c|c|c|c|c|c|c|c|c|c|}
\hline & \multicolumn{2}{|c|}{ Outdoor } & \multicolumn{5}{|c|}{ Indoor } & \multicolumn{7}{|c|}{ Digital } \\
\hline & 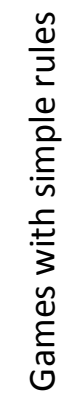 & 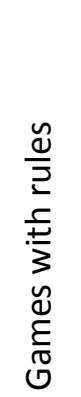 & $\begin{array}{l}\bar{\pi} \\
\stackrel{0}{0} \\
\end{array}$ & 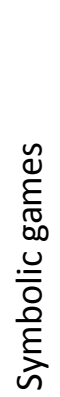 & 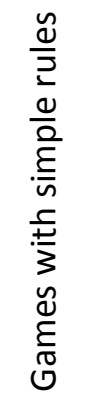 & 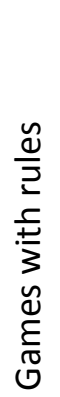 & $\begin{array}{l}\bar{\pi} \\
\stackrel{0}{0} \\
-1\end{array}$ & 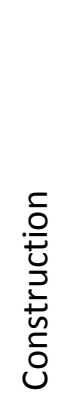 & $\begin{array}{l}n \\
\text { to } \\
\text { ñ }\end{array}$ & $\begin{array}{l}0 \\
\frac{1}{2} \\
+\frac{1}{2} \\
\frac{1}{2} \\
\frac{0}{2} \\
\frac{1}{2} \\
.0 \\
\frac{0}{2}\end{array}$ & 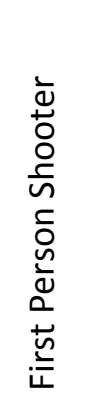 & 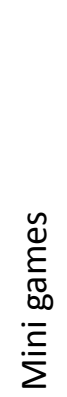 & 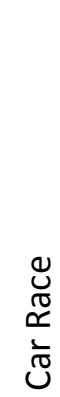 & $\begin{array}{l}\bar{\pi} \\
\stackrel{0}{0} \\
\end{array}$ \\
\hline Girl & 60 & 64 & 124 & 7 & 3 & 10 & 20 & 14 & 0 & 17 & 1 & 51 & 1 & 69 \\
\hline Boy & 19 & 98 & 117 & 3 & 1 & 3 & 7 & 27 & 85 & 18 & 24 & 4 & 11 & 127 \\
\hline Total & 79 & 162 & 241 & 10 & 4 & 13 & 27 & 41 & 85 & 35 & 25 & 55 & 12 & 196 \\
\hline
\end{tabular}

As it may be seen in Table 2, game environment preferences of the students varied across three main categories: outdoor, indoor and digital platforms; $51.9 \%$ of the participants $(\mathrm{N}=241)$ drew outdoor games, $42.2 \%(\mathrm{~N}=196)$ drew digital games and the remaining $5.8 \%$ $(\mathrm{N}=27)$ drew indoor games. Of these subcategories, outdoor game preferences of the participant students were distributed under two groups: games with simple rules and game with rules. Students preferred games with rules $(N=162)$ to games with simple rules $(N=79)$. In terms of gender, girls $(\mathrm{N}=60)$ preferred games with simple rules more than boys $(\mathrm{N}=19)$, and boys $(\mathrm{N}=98)$ preferred games with rules more than girls $(\mathrm{N}=64)$.

Similar to the subcategories of outdoor games, indoor game preferences of the participants were in three groups: symbolic games $(\mathrm{N}=10)$, games with simple rules $(\mathrm{N}=4)$ and games with rules $(\mathrm{N}=13)$. The results indicated that students generally preferred not to play indoors. On the other hand, compared to boys, girls were more likely to prefer indoor games, and in general, the students preferred playing games with rules $(\mathrm{N}=13)$ and symbolic games $(\mathrm{N}=10)$ rather than games with simple rules $(\mathrm{N}=4)$. Table 2 shows drawings of the students' indoor game preferences.

As it may be seen in Table 3, the most frequently played digital games were construction games $(N=50)$ that students have control over in terms of time such as Farmville and Minecraft and these were more likely to be preferred by boys and played on PC. Other popular digital games were played on PlayStation and sportive games $(\mathrm{N}=48)$ such as football. Girls had not drawn any sportive PlayStation games. Downloadable mini games such as Pou, Monster Academy, doll dress up or cooking games were more likely to be played on computer and preferred by girls $(\mathrm{N}=39)$. Action-adventure games including Minion Rush and Temple Run were played by both girls and boys $(\mathrm{N}=35)$. However, girls preferred to play these games on the computer whereas boys preferred them on tablets. First person shooter violent video games such as Counter Strike, Call of Duty and Legend Online $(\mathrm{N}=29)$ and race games like Car Race $(\mathrm{N}=13)$ were most likely to be preferred by boys. The environments they mostly frequently preferred while playing digital games were mostly PC $(N=119)$, secondly PlayStation $(\mathrm{N}=48)$ and thirdly tablets or smartphones $(\mathrm{N}=29)$. Students' outdoor and indoor game preferences and related drawings are presented in Table 3. 
Table 3. Students' Indoor and Outdoor Game Preferences and Related Drawings

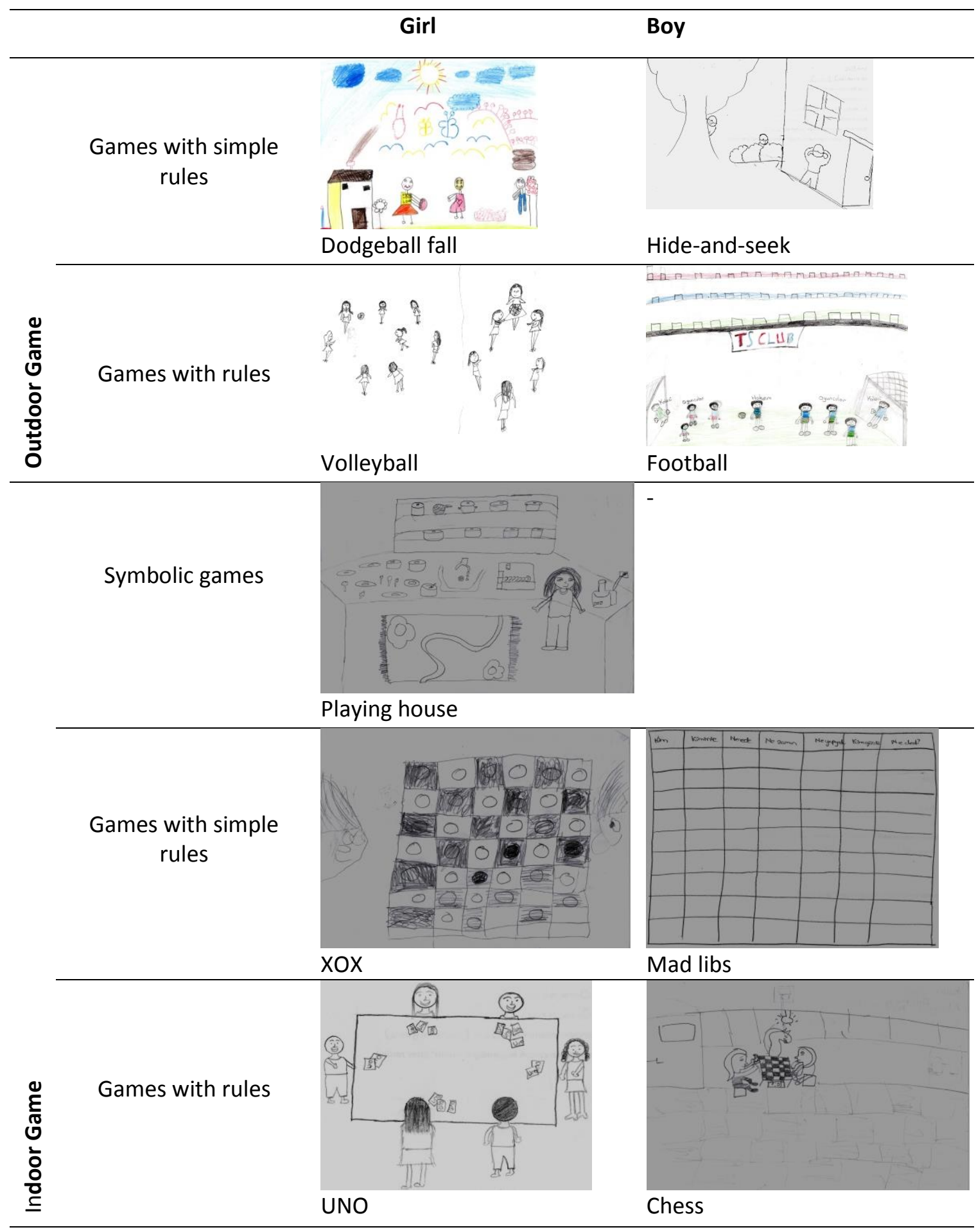

As shown in Table 3, games such as Dodgeball Fall, Hide and Seek were under the subcategory "games with simple rules" whereas games such as volleyball and football were subcategorized as "games with rules". No symbolic game was drawn under the category of outdoor games. In the subcategories of indoor games; symbolic games included role-playing games such as playing house or playing doctor. Games with simple rules included mad libs and XOX and 
games with rules included table games such as chess, Monopoly, sudoku and UNO. The digital game preferences of the students are summarized in Table 4.

Table 4. Subcategories of Students' Digital Platform Game Preferences and Their Related Drawings

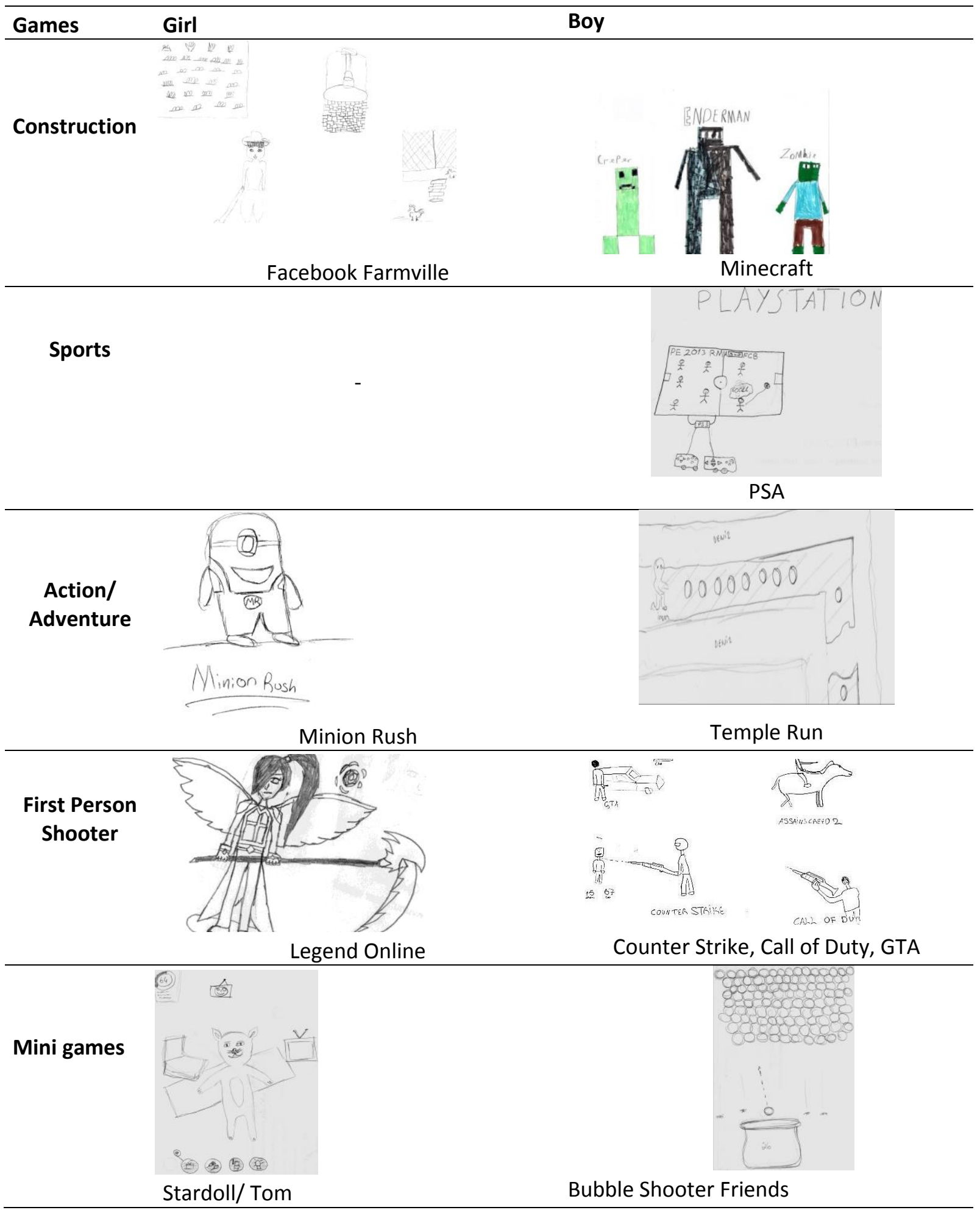




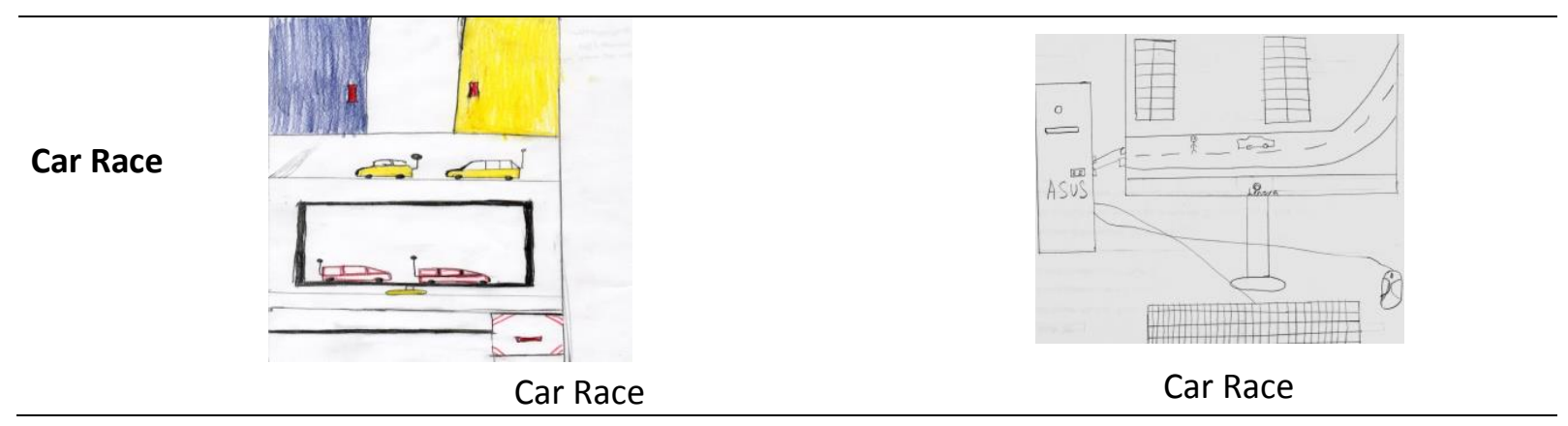

According to Table 4, it was seen that the games the participants played in the digital environment included construction games such as Facebook Farmville and Minecraft, sports games on PlayStation, action/adventure games such as Minion Rush and Temple Run, first person shooter games such as Legend Online and GTA, mini games such as Tom, Bubble Shooter Friends, or Car Race.

\section{Findings Regarding the Variables Affecting Students' Game Preferences}

The findings of the CHAID analysis on the effects of various variables such as gender, availability of Internet connection, grade in school, education levels of parents on students' game preferences are presented in Figure 6.

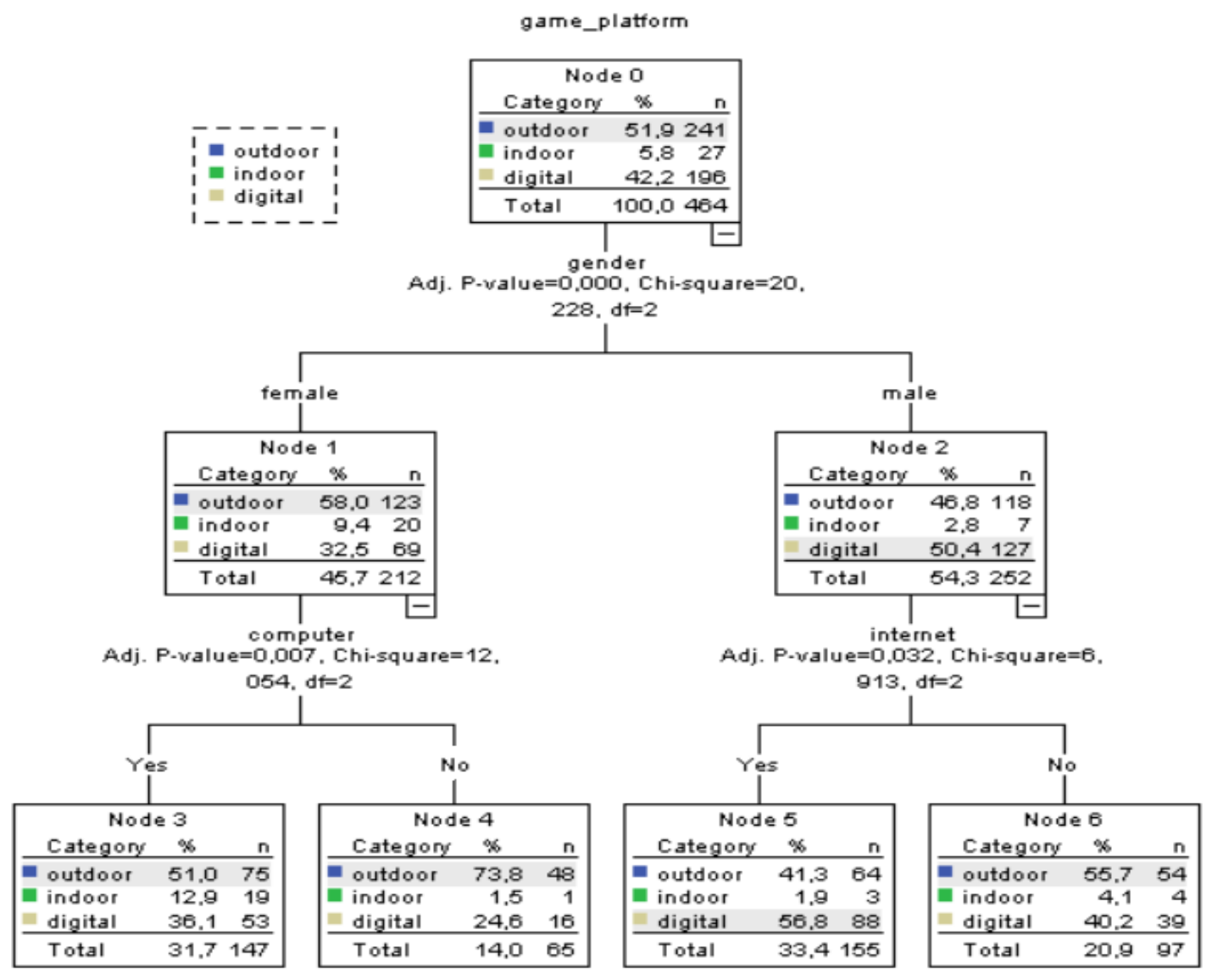

Figure 6. CHAID Decision Tree Regarding Game Environments 
Gender was found to be the best predictor variable in terms of predicting students' game zone preferences $\left(\alpha 2_{(2,464)}=20.228, p<.05\right)$. While $58 \%$ of the girls preferred playing outdoors, $\% 9.4$ preferred playing indoors and the remaining $32.5 \%$ preferred digital platforms for playing games. As for boys, $46.8 \%$ preferred playing outdoors, only $2.8 \%$ of them preferred indoors while $50.4 \%$ preferred digital platforms for playing games. These results indicate that both girls and boys disfavored playing indoors. Additionally, girls were more likely to prefer outdoors while boys mostly preferred digital platforms for playing.

Predictor variables other than gender that predicted students' game zones included having a PC at home for girls, while for boys, these included having an available Internet connection at home. Having a computer at home or not had a statistically significant effect on girls' game zone preferences $\left(\chi_{(2,212)}^{2}=12.054, p<.05\right)$. For girls who had computers at home $(n=147), 51 \%$ preferred playing outdoors, $12.9 \%$ prefer playing indoors and $36 \%$ preferred digital games. Among the girls with computers at home, the majority still preferred playing outdoors to playing on a computer. Girls were less likely to prefer digital platforms as a game zone.

Among girls who did not have a computer at home $(n=65), 73.8 \%$ preferred playing outdoors, $24.6 \%$ preferred digital platforms and the remaining $1.5 \%$ preferred playing indoors. These percentages indicated that girls who did not have computers at home were more likely to prefer playing outdoors.

Internet was found to have no significant effect on game zone preferences of girls while it significantly affected boys' game zone preferences $\left(\chi^{2}(2,212)=6.13, p<.05\right)$. When we look at the percentage distribution of male students who had an available Internet connection $(n=155)$, $41.3 \%$ played outdoors, $1.9 \%$ preferred indoors and $56.8 \%$ preferred digital platforms. This distribution indicates that majority of the boys who had Internet connection were most likely to prefer digital platforms as playing zones.

For boys who did not have an available Internet connection ( $n=97), 55.7 \%$ preferred playing outdoors, $4.1 \%$ preferred indoors and $40.2 \%$ preferred digital games. In other words, boys who had Internet connection were more likely to prefer playing digital games. On the other hand, having a computer or not did not affect boys' game zone preferences.

Students' grades in school and education levels of their parents were not found to have a significant effect on their game zone preferences. In other words, these variables did not predict students' choice places for playing games.

\section{Discussion and Recommendations}

This study is one of the limited number of studies which have been conducted with the aim of determining the game playing preferences of students in Turkey, not only in digital but also in traditional settings. Rapidly increasing prevalence of digital games brought into attention the usage of the motivating nature of this inevitable culture for education purposes. If the gamerelated preferences of children are understood, the motivation factors of games may also be used in the education system. This way, both interesting and more lasting learning settings may be created. A limited number of studies in the literature reported that, in online-only games on a digital environment in general, the age groups of concern are older than 12 years 
and children are not usually included in such studies. This study aimed to reveal whether the gaming preferences of middle school students differed in terms of setting, gender, class level, socioeconomic level of the family, and whether they had computers or Internet access.

There are several studies that have shown that children's game choices are affected by different variables (Kinzie \& Joseph, 2008; Kuhaneck, Spitzer \& Miller, 2010). Some of these studies found that game preferences of children vary across age and across newly developed skills (Christoph, Dorothée, Peter, 2009; Marouf, Che-Ani \& Tawil, 2015; Quaiser-Pohl, Geiser, Lehmann, 2006). Another variable that affects game preferences of children is gender, although the underlying reasons cannot be explained clearly (Inal \& Cagiltay, 2005; Miller \& Kuhaneck, 2008). This study identified gender as the best predictor variable in terms of students' game preferences. Although the content of preferred games changes over time, gender remains constant as a variable affecting game preference (Case-Smith \& Miller Kuhaneck, 2008; Miller \& Kuhaneck, 2008).

Girls tend to prefer playing outdoors while boys prefer playing digital games. Compatibly, Pala and Erdem (2011) found a significant relationship between gender and game preferences of children in their study which focused on digital game preferences of students. In general, boys tend to play digital games for entertainment and relaxation while girls are more likely to play digital games for educational purposes (Bonnano \& Kommers, 2008; Erboy \& Vural, 2010). While female students mostly like to play games that have rules played outside like volleyball, male students mostly prefer playing sports games like football games played on a PlayStation or a computer. It is noticeable that the type of games female students mostly preferred in the digital environment were mini games such as cake baking or doll dressing, while sports games were not drawn by any female students. The findings in this study were in agreement with those in the literature that girls like to play non-violent package games such as puzzles, make up games while boys prefer games that contain action and adventure, and sports games that sometimes contain violence (Benenson, 1993; Buchman \& Funk, 1996; Hartmann \& Klimmt, 2006; Inal \& Cagiltay, 2005; Karakus, Inal \& Cagiltay, 2008; Karakus, Lucas \& Sherry, 2004; Klawe et al., 2002; Pellegrini, 1992; Romrell, 2013; von Salisch, Oppl \& Kristen, 2006).

This study found gender being insignificant in terms of affecting digital game preferences of the students. According to the analysis of the participant drawings in the context of this study, it was seen that the least frequently drawn games were indoor games by both girls and boys. Although parents would like their children to prefer outdoor games, they are aware of the fact that technology is very appealing to them (Downey, Hayes \& Brian, 2004). In recent years, rapid developments in technology have led to an increase in the number of digital games in the market and caused a shift in children's game preferences from outdoors to digital platforms (Van Rheenen, 2012). With the rise in popularity of digital games, children's interest in indoor games and sedentary games of the past have diminished (Downey, Hayes \& Brian, 2004; Serbin, Bohlin \& Berlin, 1999; Van Rheenen, 2012).

Another important finding of the study is that, predictor variables for students were found to be "having a computer" for girls and "having an available Internet connection" for boys. Among a variety of digital platforms, computers were found to be the first coming to students' minds followed by PlayStation, tablets and smartphones. Some studies showed that having a PC increases the average time spent playing games and has effects on game preferences (Inal \& Cagiltay, 2005; Onay, Tufekci \& Cagiltay, 2005; Sherry, Holmstrom, Binns, Greenberg \& Lachlan, 2003). In line with the mentioned studies, this study found that "having a computer" 
is a significant factor affecting especially girls' game preferences. Participant girls were divided into two groups based on whether they had a computer. Both groups' first choice was playing outdoors; however, girls who did not have a computer preferred to play outdoors in a greater proportion. It may be argued that passing times shifted the game preferences of male students into the digital environment.

The most important factor affecting boys' game preferences was "having an Internet connection". Boys who had Internet connection available at home tended to show more interest in digital platforms in comparison to other playing zones. It could be stated that having an Internet connection is the reason that boys spend less time playing outdoors. Having a computer had no effect on boys' game zone preferences. Accordingly, a study conducted by Tufekci (2007) revealed that having a personal computer at home does not have a significant influence on boys' playing digital games. In other words, having a computer at home does not determine boys' computer use for playing games. Only the availability of an Internet connection affects boys' game zone preference. Therefore, all Internet connectable devices (tablet, smartphone etc.) had an influence on boys' game preferences. However, having Internet access did not affect girls' game preferences.

One of the important findings of this study is that, education levels of parents were not found to be a predictor variable for students' game preferences. There is a very limited body of literature available examining the relationship between these two variables (namely "education levels of parents" and "game preferences of children"). In general, it could be stated that parents do not provide guidance regarding game preferences and the decision (game choice) belongs to children. Additionally, it is known that sociocultural and physical environments can impact children's game preferences (Inal \& Cagiltay, 2006).

In this study, it was seen that, there was no significant relationship between grade in school and game preference. In the literature, there are studies indicating that higher levels of education lead to playing less educational games (Buchman \& Funk, 1996); there is no significant difference in game preference according to age among women (Marshall \& Foran, 2008); there is no significant relationship between grade in school and game preference (Pala \& Erdem, 2011), and game preferences among children at ages of 8-9 and 13-16 differentiate (Sherry, Desouza, Greenberg \& Lachlan, 2003). It is thought that differentiation did not exist in this study since the age range of the group of students was quite narrow.

"No proposed research project is without limitations" (Marshall \& Rossman, 1999). This study also has some limitations in a certain context in order to reveal the variables affecting students' game preferences. Further studies may be carried out in terms of the properties of the games, reflection of the games in students' real lives.

This study has three important recommendations. The first one of these is consideration of structural characteristics of girls while developing digital games for educational purposes and such games should be downloadable and playable for computers or portable devices. It is recommended to develop more dynamic MMORPG-like games with risks for male students based on their developmental characteristics at certain ages. This is because these students will not be adequately interested in and attentive for traditional educational digital games due to the dynamism and excitement of the preadolescent or adolescent periods. It is recommended to adapt the rules or actions in especially sports games they play on PlayStation into educational software using various technologies. 
As a result of the study, it was found that female middle school students preferred outdoor games, while male students preferred entertainment-oriented digital games. Therefore, another recommendation of this study is to use gamification settings where game elements (i.e. video games) are integrated into classroom environments more and consider the types of games provided in the results of this study in the process. Additionally, it is believed that the results of this study may have a leading position for future studies in the field of gamification in terms of revealing the games frequently played by students.

It is considered that the study may contribute to the field also in terms of investigating factors that affect game preferences with a different analysis approach using CHAID analysis. It is recommended for researchers to investigate the effects of traditional games on the digital games students prefer to play. It was observed in the analyses of this study that the drawings of the students differed based on types of games they represented. It is believed that, if researchers in the field work on this topic in an interdisciplinary approach, this will contribute to the field.

\section{References}

Agaoglu, O. \& Metin, N. (2015). A survey study on the $4^{\text {th }}-8^{\text {th }}$ graders in the science and arts centers who play violent PC games comparing to their school only peer group. Journal of Gifted Education Research, 3(2), 11-25.

Akpinar, Y. (1999). Bilgisayar destekli ogretim ve uygulamalar. Ankara: Ani.

Amory, A., Naicker, K., Vincent, J. \& Adams, C. (1999). The use of computer games as an educational tool: Identification of appropriate game types and game elements. British Journal of Educational Technology, 30(4), 311-321.

Amory, A. \& Seagram, R. (2003). Educational game models: Conceptualization and evaluation: The practice of higher education. South African Journal of Higher Education, 17(2), 206.

Anderson, C. A., Shibuya, A., Ihori, N., Swing, E. L., Bushman, B. J., Sakamoto, A., Rothstein, H. R. \& Saleem, M. (2010). Violent video game effects on aggression, empathy, and prosocial behavior in eastern and western countries: A meta-analytic review. Psychological Bulletin, 136(2), 151.

Anderson, C. A. \& Dill, K. E. (2000). Video games and aggressive thoughts, feelings, and behavior in the laboratory and life. Journal of Personality and Social Psychology, 78(4), 772-790.

Arabul Yayla, H. (2015). A prototype suggestion including a game based environment to support the language education of children with down syndrome (Unpublished master's thesis). Bahcesehir University, Istanbul.

Asimoglu, S. (2012). Concept of game in pre-school education with creative drama and orff approach (Unpublished master's thesis). Istanbul Technical University, Istanbul.

Aydogdu, M. \& Kesercioglu, T. (2005). Ilkogretimde fen ve teknoloji ogretimi. Ankara: Ani.

Bahar, M., Nartgun, Z., Durmus, S. \& Bicak, B. (2006). Geleneksel ve alternatif olcme ve degerlendirme ogretmen el kitabi. Ankara: PegemA. 
Bakar, A., Tuzun, H. \& Cagiltay, K. (2008). Students' opinions of educational computer game utilization: A social studies course case. Hacettepe University Journal of Education, 35, 27-37.

Barnes, P. (2004). Personal, social and emotional development of children. Oxford: Blackwell.

Batdi, V. (2017). The effect of edutainment applications upon academic achievement: A metaanalytic study. GUJGEF, 37(1), 47-62.

Bayirtepe, E. \& Tuzun, H. (2007). The effects of game-based learning environments on students' achievement and self-efficacy in a computer course. Hacettepe University Journal of Education, 33, 41-54.

Benenson, J. F. (1993). Greater preference among females than males for dyadic interaction in early childhood. Child Development, 64(2), 544-555.

Birsen, P. (2017). Effect of gamified game-based learning on 12 vocabulary retention by young learners. (Unpublished master's thesis). Bahcesehir University, Istanbul.

Bonanno, P. \& Kommers, P. A. M. (2008). Exploring the influence of gender and gaming competence on attitudes towards using instructional games. British Journal of Educational Technology, 39(1), 97-109. doi: 10.1111/j.1467-8535.2007.00732.x

Bottino, R. M, Ferlino, L., Ott, M. \& Travella, M. (2006). Developing strategic and reasoning abilities with computer games at primary school level. Computers \& Education, 49(4), 1272-1286.

Bozkurt, A. \& Genc Kumtepe, E. (2014, February). Gamification, game philosophy and education: Gamification. Academic Information'14- XVI. Academic Information Conference Proceeding (147-156). Mersin University.

Buchman, D. D. \& Funk, J. B. (1996). Video and computer games in the, 90s: Children time commitment \& game preferences. Children Today, 24(1), 12.

Caldera, Y. M., Huston, A. C. \& O'Brien, M. (1989). Social interactions and play pattern of parents and toddlers with feminine, masculine, and neutral toys. Child Development, 60(1), 70-76.

Case-Smith, J. \& Miller Kuhaneck, H. (2008). Play preferences of typically developing children and children with developmental delays between the ages 3 and 7 years. Occupational Therapy Faculty Publications, 28(1), 19-29. doi: 10.3928/15394492-20080101-01.

Cherney, i. D. \& London, K. (2006). Gender-linked differences in the toys, television shows, computer games, and outdoor activities of 5- to 13-year-old children. Sex Roles, 54(910), 717-726. doi.10.1007/s11199-006-9037-8.

Christakis, D. A., Ebel, B. E., Rivara, F. P. \& Zimmerman, F. J. (2004). Television, video, and computer game usage in children under 11 years of age. J Pediatr, 145(5), 652-659.

Christoph, K., Dorothée, H. \& Peter, V. (2009). The video game experience as "true" identification: A theory of enjoyable alterations of players' self-perception. Communication Theory, 19(4), 351-373.

Clements, R. (2004). An investigation of the status of outdoor play. Contemporary issues in Early Childhood, 5(1), 68-80. 
Csikszentmihalyi, M. (1991). Flow: The psychology of optimal experience. New York: Harper Perennial.

Cohen, L., Manion, L. \& Morrison, K. (2007). Research methods in education. London: Routledge.

Caglar, S. \& Arkun Kocadere, S. (2015). Gamification in online learning environments. The Journal of Educational Sciences and Practice, 14(27), 83-102.

Cankaya, S. (2007). The effects of computer games developed about ratio and proportion topic on students' thoughts about mathematics course and educational computer games (Unpublished master's thesis). Balikesir University, Balikesir.

Cankaya, S. \& Karamete, A. (2008). The effects of educational computer games on students' attitudes towards mathematics course and educational computer games. Mersin University Journal of the Faculty of Education, 4(2), 115-127.

Catak, G. (2011). Designing as playing: Digital design games. Sigma, 3, 385-391.

Demirel, O., Seferoglu, S. \& Yagci, E. (2003). Ogretim teknolojileri ve materyal gelistirme (4th Ed.). Ankara: PegemA.

Deterding, S., Dixon, D., Khaled, R. \& Nacke, L. (2011). From game design elements to gamefulness: Defining gamification. Paper presented at the 15th international Academic MindTrek Conference: Envisioning Future Media Environments, Tampere, Finland.

Dickey, M. D. (2007). Game design and learning: a conjectural analysis of how massively multiple online role-playing games (MMORPGs) foster instrinsic motivation. Education Technology Research Development, 55(3), 253-273.

Domínguez, A., Saenz-de-Navarrete, J., De-Marcos, L., Fernández-Sanz, L., Pagés, C. \& Martínez-Herráiz, J. J. (2013). Gamifying learning experiences: Practical implications and outcomes. Computers \& Education, 63, 380-392.

Downey, S., Hayes, N. \& Brian, O. (2004). Play and technology for children aged 4-12. Techical report. Centre for Social and Educational Research, Dublin Institute of Technology.

Ehrlén, K. (2009). Drawings as representations of children's conceptions. International Journal of Science Education, 31(1), 41-57.

Erboy, E. \& Vural, R. A. (2010). The factors which effect on computer game addiction of $4^{\text {th }}$ and $5^{\text {th }}$ grade primary students. Journal of Ege Education, 11(1), 39-58.

Esen, M. A. (2008). The instructional importance of traditional child's plays and almost forgotten akhiska child's plays. Uludag University, Journal of Educational Faculty, 21(2), 357- 367.

Fein, G. G. (1981). Pretend play in childhood an integrative review. Child Development, 52, 1095-1118.

Fis Erumit, S. (2016). Using gamification approaches in education: A design based research (Unpublished doctoral dissertation). Ataturk University, Erzurum, Turkey.

Fromme, J. (2003). Computer games as a part of children's culture, game studies. The international Journal of Computer Game Research, 3(1). Retrieved on 21 November 2017 from http://www.gamestudies.org/0301/fromme/.

Funk, J. B. (1993). Reevaluating the impact of video games. Clinical Pediatrics, 32(2), 86-90. 
Garris, R., Ahlers, R. \& Driskel, L. J. E. (2002). Games, motivations and learning: A research and practice model. Simulation \& Gaming, 33(4), 441-467.

Gentile, D. A., Lynch, P. L., Linder, J. R. \& Walsh, D. A. (2004). The effects of violent video game habits on adolescent hostility, aggressive behaviors, and school performance. Journal of Adolescence, 27(1), 5-22.

Goldstein, J. (2012). Play in children's development, health and well-being. Toy industries of Europe. Retrieved on 12 March 2015 from http://www.ornes.nl/wpcontent/uploads/ 2010/08/Play-in-children-s-development-health-and-well-being-feb- 2012.pdf.

Gunes, F. (2015). Game-based learning approach. Turkish Studies, 10(11), 773-786.

Hacisalihoglu Karadeniz, M. (2017). A general review of acquisitions and problems in the process of adapting and applying traditional children's games into maths. Kastamonu Education Journal, 25(6), 2245-2262.

Hamalainen, R. (2008). Designing and evaluating collaboration in a virtual game environment for vocational learning. Computers \& Education, 50(1), 98-109.

Harman, G. (2012). Investigation of primary school $8^{\text {th }}$ grade students' knowledge about mitosis by drawing method. Journal of Research in Education and Teaching, 1(2), 295304.

Hartmann, T. \& Klimmt, C. (2006). Gender and computer games: Exploring females' dislikes. Journal of Computer-Mediated Communication, 11(4), 910-931.

Horner, S. B., Fireman, G. D. \& Wang, E. W. (2010). The relation of student behavior, peer status, race and gender to decisions about school discipline using CHAiD decision trees and regression modeling. Journal of School Psychology, 48(2), 135-161.

Huizenga, J., Admiraal, W., Akkerman, S. \& Dam, G. (2009). Mobile game-based learning in secondary education: engagement, motivation and learning in a mobile city game. Journal of Computer Assisted Learning, 25(4), 332-344.

Huizinga, J. (2017). Homo ludens: Oyunun toplumsal islevi uzerine bir deneme (6. basim, Cev. M. A. Kilicbay). İstanbul: Ayrinti.

Inal, Y. \& Cagiltay, K. (2006). Turkish female students' attitudes toward Internet, computers and game play from the view of cultural perspectives. Technology and Teacher Education Annual, 3, 16-21.

Inal, Y. \& Cagiltay, K. (2005). Turkish elementary school students' computer game play characteristics. BILTEK 2005 International Cognition Congress, Eskisehir, Turkey.

Iwata, T., Yamabe, T., Polojarvi, M. \& Nakajima, T. (2010, January). Traditional games meet ICT: A case study on go game augmentation. Proceedings of the Fourth International Conference on Tangible and Embedded Interaction. Cambridge, Massachusetts, USA

Jenvey, V. B. \& Jenvey, H. L. (2002). Criteria used to categorize children's play: Preliminary findings. Social Behavior and Personality: An International Journal, 30(8), 733-740. doi: 10.2224/sbp.2002.30.8.733.

Johnson, B. \& Christensen, L. (2000). Educational research quantitative and qualitative approaches. Boston, MA: Allyn and Bacon. 
Karakus, T., Inal Y. \& Cagiltay, K. (2008). A descriptive study of Turkish high school students' gameplaying characteristics and their considerations concerning the effects of games. Computers in Human Behavior, 24(6), 2520-2529. doi: 10.1016/j.chb.2008.03.011.

Karamustafaoglu, O. \& Kaya, M. (2017). Teaching the subject of 'reflection and mirrors' with educational games: a case of reflective race. Journal of Inquiry Based Activities, 3(2), 4149.

Karatas, E. (2014). Gamification in education: Research trends. Ahi Evran University Journal of Kirsehir Education Faculty, 15(2), 315-333.

Karlsson, M. (2007). Teacher educators moving from learning the office package to learning about digital natives' use of ICT. In C. Montgomerie \& J. Seale (Eds.), Proceedings of EDMEDIA 2007-World Conference on Educational Multimedia, Hypermedia \& Telecommunications (pp. 100-107). Retrieved on 23 November 2017 from https://www. learntechlib.org/p/25364/.

Kass, G. V. (1980). An exploratory technique for investigating large quantities of categorical data. Applied Statistic, 29(2), 119-127. doi: 10.2307/2986296.

Kearney, P. \& Pivec, M. (2007). Recursive loops of game-based learning: a conceptual model. In C. Montgomerie \& J. Seale (Eds.), Proceedings of ED-MEDIA 2007-World Conference on Educational Multimedia, Hypermedia \& Telecommunications (pp. 2546-2553). Retrieved on 23 November 2017 from https://www.learntechlib.org/p/25731/.

Kiili, K. (2005). Digital game-based learning: Towards an experiential gaming model. The Internet and Higher Education, 8(1), 13-24.

Kilmen, S. \& Kosterelioglu, I. (2017). Examination of teachers' perceptions towards alternative assessment approaches with CHAiD analysis. Elementary Education Online, 16(1), 256273.

Kinzie, M. B. \& Joseph, D. R. D. (2008). Gender differences in game activity preferences of middle school children: implications for educational game design. Educational Technology Research \& Development, 56, 643-663.

Klawe, M. (2002). Girls, boys, and computers. ACM SiGCSE Bulletin, 34(2), 16-17.

Korkusuz, M. E. \& Karamete, A. (2013). Educational game development models. Necatibey Faculty of Education Electronic Journal of Science and Mathematics Education, 7(2), 78109.

Kuhaneck, H. M., Spitzer, S. \& Miller, E. (2010). Activity analysis, creativity, and playfulness in pediatric occupational therapy: Making play just right. Boston: Jones and Bartlett.

Kula, A. \& Erdem, M. (2005). The effect of educational computer games on the development of basic arithmetical operation skills. Hacettepe University Journal of Education, 29, 127136.

Kurt, H., Ekici, G., Aktas, M. \& Aksu, O. (2013). Determining biology student teachers' cognitive structure on the concept of "diffusion" through the free word-association test and the drawing-writing technique. International Education Studies, 6(9), 187-206.

Lenhart, A. (2015). Teens, social, media \& technology overview. Retrieved on 12 March 2015 from: http://www.pewinternet.org/files/2015/04/Pi_TeensandTech_Update2015_ 0409151.pdf 
Lucas, K. \& Sherry, J. L. (2004). Sex differences in video game play: A communication based explanation. Communication Research, 31(5), 499-523.

Marouf, N., Che-Ani, A. I. \& Tawil, N. M. (2015). Examining physical activity and play behavior preferences between first graders and last graders in primary school children in Tehran. Asian Social Science, 12(1), 17.

Marshall, A. \& Foran, J. (2008, December). Australian female gamers video game preferences. Paper presented at the Australian \& New Zealand Marketing Academy Conference (pp. 1-3).

McFarlane, A., Sparrowhawk, A. \& Heald, Y. (2002). Report on the educational use of games. Cambridge: TEEM (Teachers Evaluating Educational Multimedia).

McInnes, K. \& Birdsey, N. (2013, July). Understanding play: The perceptions of children, adolescents, parents and teachers. In 2nd Global Conference: Making Sense of Play. Oxford, UK. Retrieved on 12 March 2015 from https://www.interdisciplinary.net/ probing-the-boundaries/wpcontent/uploads/2013/05/mcinnesplaypaper.pdf.

McMillian, J. H. \& Schumacher, S. (2001). Research in education: A conceptual introduction. New York: Longman.

Michael, J. \& Gordon, S. (2004). Data mining technique for marketing, sales and customer support (2nd Ed.). New York: Wiley.

Miller, E. \& Kuhaneck, H. (2008). Children's perceptions of play experiences and the development of play preferences: a qualitative study. American Journal of Occupational Therapy, 62(4), 407-415.

Nedim Bal, P. \& Metan, H. (2016). The effect of computer addiction management psychotraining program on 9th grade students. Abant Izzet Baysal University Journal of Faculty of Education, 16(1), 62-74.

Neesen, K. (2008). The online gaming preferences of pre-teen girls: exploring game preferences within the social context of an all-girls after school computer club (Unpublished doctoral dissertation). The Faculty of the Curry School of Education University of Virginia, Virginia, USA.

Onay, P., Tufekci, A. \& Cagiltay, K. (2005). A Comparative study between METU and Gazi University students: Game playing characteristics and game preferences of university students. Eurasian Journal of Educational Research, 19, 6-76.

Oxford (2016). Play. Retrieved on 28 January 2016 from: http://www.oxforddictionaries. com/definition/english/play

Pala, F. K. \& Erdem, M. (2011). A study on the relationships between digital game preference and game preference reason with gender, class level and learning styles. Journal of Kirsehir Education Faculty, 12(2), 53-71.

Parsons, A. (2011). Young children and nature: Outdoor play and development, experiences fostering environmental consciousness, and the implications on playground design. (Unpublished doctoral dissertation). Virginia Polytechnic Institute and State University, Virginia, Virginia, USA.

Pellegrini, A. D. (1992). Preference for outdoor play during early adolescence. Journal of Adolescence, 15, 241-254. 
Pilten, P. \& Pilten, G. (2013). Evaluating the perceptions of school-aged children about game concept and game preferences. Mersin University Journal of the Faculty of Education, 9(2), 15-31.

Prensky, M. (2001). Digital game-based learning: Fun, play and games. What makes games engaging? New York: McGraw-Hill.

Prensky, M. (2002). The motivation of gameplay: The real twenty-first century learning revolution. On the Horizon, 10(1), 5-11. doi: 10.1108/10748120210431349.

Prensky, M. (2003). Digital game-based learning. ACM Computers in Entertainment, 1(1), 1-4.

Quaiser-Pohl, C., Geiser, C. \& Lehmann, W. (2006). The relationship between computer-game preference, gender, and mental-rotation ability. Personality and Individual Differences, 40(3), 609-619.

Romrell, D. (2014). Gender and gaming: A literature review. Proceedings of the annual meeting of the AECT International Convention (pp. 11-22). Hyatt Regency Orange County, Anaheim, CA.

Serbin, A., Bohlin, G. \& Berlin, L. (1999). Sex differences in 1-, 3-, and 5-year-olds' toy-choice in a structured play-session. Scandinavian Journal of Psychology, 40, 43-48.

Sherry, J. L., Holmstrom, A., Binns, R., Greenberg, B. S. \& Lachlan, K. (2003, November). Gender differences in video game use and preferences. Paper presented at the National Communication Association Annual Convention. Miami, FL.

Sherry, J., Desouza, R., Greenberg, B. \& Lachlan, K. (2003, May). Relationship between developmental stages and video game uses and gratifications, game preference and amount of time spent in play. Paper presented at the International Communication Association Annual Convention. San Diego, CA.

SPSS (2012). IBM SPSS decision trees 21. Retrieved on 15 June 2015 from http://www.sussex. ac.uk/its/pdfs/SPSS_Decision_Trees_21.pdf

Sahin, Y. L., Karadag, N., Bozkurt, A., Dogan, E., Kilinc, H., Ugur, S., Gumus, S., Ozturk, A. \& Guler, C. (2017). The use of gamification in distance education: a web-based gamified quiz application. Turkish Online Journal of Qualitative Inquiry (TOJQI), 8(4), 372-395. doi: 10.17569/tojqi.

Sahin, C., Ipek, H. \& Ayas, A. (2008). Teaching the subject of 'reflection and mirrors' with educational games: a case of reflective race, Asia Pacific Science on Learning, 9(1), 7.

Tolay, T. (2013). Critical view on popular culture's effects on child's literature and child plays. Science and Culture, 2, 154-16.

Tugrul, B., Erturk, H. G., Ozen Altinkaynak, S. \& Gunes, G. (2014). Change of the play in three generations. The Journal of Academic Social Science Studies, 27, 1-16.

Tufekci, A. (2007). A study of student habits on playing computer games. The Journal of industrial Arts Faculty of Gazi University, 21, 38-54.

Tural, H. (2005). The effects of teaching mathematics in elementary school by games and activities on achievement and attitude (Unpublished master's thesis). Dokuz Eylul University, Izmir, Turkey. 
Ture, M., Kurt, I., Kurum, A. T. \& Ozdamar, K. (2005). Comparing classification techniques for predicting essential hypertension. Expert Systems with Applications, 29, 583-588.

URL1 (2017). MEB'den egitimde mobil oyun donemi. Retrieved on 15 November 2017 from http://www.hurriyet.com.tr/mebden-egitimde-mobil-oyun-donemi-40644390.

Van Rheenen, D. (2012). A century of historical change in the game preferences of American children. Journal of American Folklore, 125(498), 411-443.

Von Salisch, M., Oppl, C. \& Kristen, A. (2006). What attracts children? İn P. Vorderer \& J. Bryant (Eds.), Playing video games: Motives, responses and consequences (pp. 147-163). Hillsdale, NJ: Erlbaum.

Vanc, K., Miller, K. \& Hand, B. (1995). Two examples of using constructivist approaches to teach ecology at the middle school level. The American Biology Teacher, 37(4), 244-249.

Yengin, D. (2012). Dijital oyunlarda siddet. Istanbul: Beta.

Yildirim, H. \& Simsek, A. (2011). Sosyal bilimlerde nitel arastirma yontemleri. Ankara: Seckin.

Yildiz, D. (2006). CHAID analysis and an application (Unpublished master's thesis). Yildiz Technical University, Istanbul.

Yilmaz, B. (2008, May). Analysing the computer addiction aptitudes of 6 th and 7 th grades students according to different variables. Paper presented at the 6th International Educational Technology Conference. Anadolu University, Eskisehir, Turkey.

Zhong, Z. (2011). The effects of collective MMORPG (Massively Multiplayer Online Role-Playing Games) play on gamers' online and offline social capital. Computers in Human Behavior, 27(6), 2352-2363.

Correspondence: Zeynep Tatli, Assistant Professor, Department of Computer Education and Instructional Technologies, Fatih Faculty of Education, Karadeniz Technical University, Trabzon, Turkey 